\title{
THE CRITICS OF THOMAS LICKONA'S CHARACTER EDUCATION: ISLAMIC PSYCHOLOGY PERSPECTIVE
}

\author{
Yandi Hafizallah \\ IAIN Syaikh Abdurrahman Siddik Bangka Belitung, Indonesia \\ yandihafiz@iainsasbabel.ac.id
}

\begin{abstract}
This paper aims to explain the concept of Thomas Lickona's character education based on the study of Islamic psychology. Thomas character education is an educational design oriented to moral knowledge, moral feelings, and moral action. Overall character education can be defined as a way of thinking and behaving based on aspects of knowledge (cognitive), feelings, and action. The Islamic psychology is considered relevant in examining aspects of psychology contained in Thomas Lickona's character education. Islamic psychology is literally a science that discusses human behavior and soul based on an Islamic perspective. The existence of a paradigm similarity in the character education of Thomas Lickona and Islamic Psychology is in terms of moral values in Islam called morality. Islamic psychology has three concepts on how to implement a value, namely, aspects of Jismiah, Nafsiyah, and Ruhaniah are concepts in character building, which means there will be integrated structures in realizing the ideal character shape in the scientific frame of Islamic psychology.
\end{abstract}

Keywords: Character Education, Islamic Psychology, Jismiah, Nafsiyah, Ruhaniah, Thomas Lickona.

\begin{abstract}
Abstrak: Tulisan ini bertujuan untuk menjelaskan konsep pendidikan karakter Thomas Lickona berdasarkan dengan kajian psikologi Islam. Pendidikan karakter Thomas merupakan desain pendidkan yang berorientasi pada pengetahuan moral, perasaan moral, dan aksi moral. Secara keseluruhan pendidikan karakter dapat didefinisikan sebagai cara berpikir dan berperilaku yang didasari oleh aspek pengetahuan (cognitive), perasaan (feeling), dan tindakan (action). Adapun psikologi Islam dianggap relevan dalam mengkaji aspek-aspek psikis yang terkandung di dalam pendidikan karakter Thomas Lickona. Psikologi Islam secara harfiah merupakan ilmu yang membahas perilaku maupun jiwa manusia berdasarkan perspektif Islam. Adanya kesamaan paradigma dalam pendidikan karakter Thomas Lickona dan Psikologi Islam ialah dalam hal nilai-nilai moral yang di dalam islam disebut dengan akhlaq. Psikologi Islam memiliki tiga konsep tentang bagaimana mengimplementasikan sebuah nilai yaitu, aspek Jismiah, Nafsiyah, dan Ruhaniah adalah konsep dalam membangun karakter (character building), yang artinya akan ada struktur-struktur yang ter-integrasi dalam mewujudkan bentuk karakter ideal dalam bingkai keilmuan psikologi Islam.
\end{abstract}

Kata kunci: Pendidikan Karakter, Psikologi Islam, Jismiah, Nafsiyah, Ruhaniah, Thomas Lickona. 


\section{PENDAHULUAN}

Saat ini pendidikan karakter menjadi sangat populer di Indonesia, hal ini dikarenakan maraknya persoalan yang berkaitan dengan tindakan-tindakan amoral yang dilakukan anak bangsa. Thomas Lickona (2004) salah satu tokoh terkemuka dalam pengembangan pendidikan karakter memberikan statment populer "sebuah negara diambang kehancuran, ketika karakter suatu bangsa telah tergadai". Persoalan-persoalan yang perlahan meracuni kaum muda di Indonesia mulai mendapatkan perhatian serius dari pemerintah. Kementerian Pendidikan dan kebudayaan menyerukan suatu gerakan yang dinamakan Penguatan Pendidikan Karakter (PPK) yang diatur dalam permendikbud No. 20. Thn. 2018 (Lubis, 2018). Gerakan ini bertujuan untuk menjadikan institusi-institusi sebagai wadah dalam mempelopori pendidikan karakter di Indonesia.

Permasalahan di atas setidaknya dibuktikan oleh studi yang menunjukkan bahwa pendidikan karakter berkontribusi pada turunnya segala bentuk kedisiplinan, dan semua hal yang berbau amoral (Beachum \& McGray, 2005). Pendidikan karakter tidak hanya terbatas pada pendekatanpendekatan yang terkait dengan aspek pendidikan saja, melainkan telah menjalar kedalam aspek-aspek lain khususnya Agama. Pendidikan karakter secara intelektual sangat berpegang pada prinsip dan nilai-nilai dari moral itu sendiri, yang bercermin kepada seorang teladan sebagai panduan dalam pelatihan moral (Watson, 2019). Islam memiliki figur yang sangat tepat dalam mencermikan karakter ideal yang dicerminkan dalam diri Nabi Muhammad SAW (Madjid, 2012). Namun pada prakteknya pendidikan karakter yang dilegitimasi oleh dunia barat menimbulkan pro dan kontra, khususnya pendidikan karakter Thomas Lickona.

Pendidikan barat secara historis mengintegrasikan pengembangan karakter berbasis agama kedalam konsep pendidikan baik sekolah maupun universitas. Tetapi dalam lingkup aktualisasinya, beragamnya latar belakang agama menyebabkan pendidikan karakter yang berbasis pada agama beserta aspek-aspeknya berkurang di sekolah-sekolah maupun di tingkat universitas (Reilly \& Narvaez, 2018). Tidak bisa dinafikan bahwa Indonesia adalah negara yang berlandaskan pada pancasila, dimana sila pertama menyatakan secara jelas dan tegas bahwa negara ini berdasarkan atas Ketuhanan Yang Maha Esa. Thomas Lickona secara gamblang memisahkan antara moralitas dengan alasan-alasan rasionalitas. Menurut hemat Lickona, agama bukanlah urusan sekolah negeri (pendidikan), dan pendidikan karakter tidak ada sama sekali hubungannya dengan kegiatan ibadah dan doa-doa (Madjid, 2012). Hal ini sangat kontradiktif dengan pandangan psikologi Islam terkait dengan pendidikan karakter Lickona. Psikologi Islam memandang bahwa karakter merupakan personifikasi dari "akhlak" yang diturunkan dari semua aspek 
ajaran Islam. Pola karakter dalam pandangan Islam ter-integrasi dalam aspek-aspek rukun Iman (aqidah), rukun Islam (syariah), dan rukun ihsan (akhlaq) (Mujib, 2012).

Jika pendidikan karakter dipahamai secara apriori, konservatif, dan bebas nilai seperti yang dinyatakan oleh Lickona diatas, maka sejatinya pendidikan karakter hanya mengembangkan kaum muda untuk sukses di dunia kerja saat ini (Sanderse, 2019), hal ini tentunya sangat bertolak belakang dengan ajaran-ajaran Islam itu sendiri. Tujuan dari tulisan ini adalah membangun pandangan kritis terhadap apa yang terjadi pada pendekatan pendidikan karakter Thomas Lickona, yang mana akan ditempuh dengan mengeksplorasi persamaan antara pendekatan pedidikan karakter Lickona dengan pendekatan karakter dalam kajian psikologi Islam. Tulisan ini memiliki tiga bagian. Pada bagian pertama akan membahas tentang pendidikan karakter Thomas Lickona, bagian kedua akan membahas mengapa masuk akal untuk membuat legitimasi psikologi Islam dalam memahami pendidikan karakter dan menjelaskan apa yang dicita-citakan psikologi Islam terhadap pendidikan karakter. Bagian ketiga akan membahas komparasi dan kritik antara pendidikan karakter Lickona dengan pendidikan karakter dalam kajian psikologi Islam.

\section{PENDIDIKAN KARAKTER THOMAS LICKONA}

Thomas Lickona adalah seorang ahli psikologi perkembangan dan pendidikan. Dia adalah salah satu pengagas dalam kajian pengembangan otoritas-otoritas moral yang membuatnya terkenal dikalangan internasional (Lickona, 2013). Riwayat pendidikan Lickona dimulai ketika dia menempuh program sarjana di Sienna College pada tahun 1964 dan Ohio University di tahun 1965, sedangkan gelar doktornya pada bidang psikologi diperoleh ketika menempuh pendidikan di State University of New York (Lickona, 2012). Salah satu karya Lickona yang membangun konstruk pendidikan karakter secara universal adalah "Moral Development E Behavior", karya ini banyak dipuji di kalangan intelektual karena dianggap berhasil dalam melakukan interpretasi pendidikan moral secara utuh dan operatif.

Perhatian Thomas Lickona terhadap nilai-nilai karakter dan pengembangannya telah menjadi kajian yang sering diperbincangkan akhir-akhir ini. Lickona berfokus pada bagaimana menerapkan nilai-nilai karakter dengan instrumen-instrumen sederhana akan tetapi memiliki dampak yang sangat besar dikemudian hari. Lickona mengemukakan bahwa karakter yang sesuai dengan sudut pandang moral adalah karakter yang terdiri dari nilai-nilai operatif atau nilai-nilai yang berfungsi dalam kaidah praktek (Maragustam, 2016). Pertanyaan mendasar timbul bagaimana seharusnya pendidikan mampu menumbuhkan nilai-nilai karakter yang operatif sehingga menghasilkan sebuah karakter yang berlandaskan dengan nilai-nilai yang 
baik. Lickona berpendapat bahwa karakter mampu mengalami pertumbuhan yang membuat suatu nilai menjadi budi pekerti, sebuah watak yang dapat diandalkan dan digunakan untuk merespon berbagai situasi dengan cara yang bermoral (Albertus, 2011).

Sebelum membahas apa pengertian pendidikan karakter dari sudut pandang Lickona, ada baiknya kita memahami apa itu pendidikan karakter secara universal. "karakter" berasal dari bahasa latin, yaitu "kharakter", "kharassein", dan "kharax", yang bermakna "tools for making", dan "pointed staked" (Wibowo, 2012). Dalam psikologi Belanda dan Jerman kata "karakter" sering diartikan sebagai pribadi, dan secara konsep merupakan kebiasaan hidup sehari-hari (Sihotang, 2018). Sedangkan dalam literatur Islam berhubungan dengan istilah khuluq (jamak: akhlak), Al-Ghazali mengungkapkan bahwa karakter adalah keadaan jiwa yang mapan yang bersifat komprehensif dalam setiap aspek kehidupan, yang artinya bahwa karakter merupakan sebuah hasil dari masalah terminologi antara pendidikan moral, dan pendidikan nilai (Alhamdani, 2014). Tentunya aspek-aspek apa sebenarnya karakter itu merupakan hal yang sangat kompleks, karena mengandung unsurunsur sosial-psikologi-budaya pada tiap individu yang didasari pada nilainilai moral (Berkowitz \& Bier, 2004). Hal ini jika kita tarik dalam lingkup pengertian pendidikan karakter, maka pendidikan karakter dapat didefinisikan sebagai cara berpikir dan berperilaku yang didasari oleh aspek pengetahuan (cognitive), perasaan (feeling), dan tindakan (action) (Wibowo, 2004).

Gambaran di atas setidaknya mampu merepresentasikan apa itu pendidikan karakter secara universal. Pertanyaan mendasar timbul tentang bagaimana karakter dapat terbentuk atau membuat relasi integral sehingga dapat membentuk karakter ideal? Thomas Lickona menyatakan bahwa pendidikan karakter haruslah memiliki nilai-nilai operatif atau nilai-nilai yang berfungsi dalam praktek (Lickona, 2013). Lickona menyatakan bahwa karakter mampu mengalami pertumbuhan yang membuat suatu nilai menjadi budi pekerti, sebuah watak batin yang dapat digunakan untuk merespon berbagai situasi dengan cara yang bermoral (Albertus, 2011). Atas dasar konstruksi inilah Lickona merumuskan bahwa karakter terbentuk dari tiga macam bagian yaitu, pengetahuan moral, perasaan moral, dan perilaku moral. Pemikiran ini pada dasarnya timbul atas penolakan Lickona terhadap "logical postivism" yang memperkenalkan perbedaan mendasar antara "fakta" dan "nilai" (Lickona, 2009).

Desain pemikiran terbentuknya karakter menurut Lickona diklaim dapat dengan efisien mampu membentuk kematangan moral seseorang. Singkatnya karakter yang ideal menurut Lickona adalah "karakter yang terdiri atas kebaikan, menginginkan kebaikan, melakukan kebaikan, kebiasaan pikiran, kebiasaan hati, dan kebiasaan perbuatan 
(Lickona, 2013). Tentunya pemikiranpemikiran ini tidak hanya view pada tataran pemikiran saja, Lickona menyatakan bahwa karakter harus memenuhi syarat dari nilai-nilai operatif. Kedudukan moral dan nilai adalah komponen dasar dalam upaya mewujudkan karakter yang baik. Menurutnya pola dasar dari pemikiran pendidikan karakter adalah komponen-komponen karakter yang harus bersifat operatif-aplikatif (Lickona, 2004). Komponen ini terdiri pengetahuan moral (moral knowing), perasaaan moral (moral feeling), dan aksi moral (moral action).

\section{Moral Knowing}

Pada aspek ini Lickona

menjelaskan bagaimana memanfaatkan pengetahuan (knowledge) untuk menyikapi tantangan-tantangan dalam hidup. Aspek ini terdiri dari enam tahapan, yang mana goals dari tahapan-tahapan tersebut adalah syarat dalam "eksisitensi" komponen-komponen berikutnya. Tahap pertama adalah kesadaran moral, aspek ini menjelaskan tentang kegagalan moral yang sering terjadi pada diri manusia dalam semua tingkatan. Lickona merumuskan tahapan ini dengan istilah "kebutaan moral", yaitu kondisi dimana individu tidak mampu melihat bahwa situasi yang sedang dia hadapi melibatkan masalah moral dan membutuhkan pertimbangan yang lebih jauh (Lickona, 2004). Kebutaan moral setidaknya sering kita temui di lingkungan sehari-hari, seringkali setiap perbuatan yang dilakukan oleh seseorang tidak mempertanyakan "apakah ini benar?". Fungsi dari pengetahuan moral adalah untuk mengajarkan kepada seseorang hal-hal yang bersifat konfirmatif, yang menurut Lickona pengetahuan moral memegang peran sebagai filter dari sebuah informasi yang masuk sebelum keputusan moral diambil.

Tahap kedua adalah mengetahui nilai-nilai moral, tahapan ini sangat mengedepankan nilai-nilai menghormati kehidupan, bertanggung jawab, kejujuran, keadilan, toleransi, sopan santun, disiplin diri, integritas, belas kasih, kedermawanan, dan keberanian (Lickona, 2004). Aspek ini sangat bersifat situasional, dimana setiap individu dituntut untuk memiliki pemahaman akan berbagai kondisi moral yang sedang dihadapi. Hal ini didasari pada pentingnya seorang individu dalam menerjemahkan hal-hal abstrak untuk dipersonifikasikan kedalam sebuah tindakan konkret. Tahap ketiga ialah pengambilan perspektif, Lickona menjabarkan pada aspek ini individu harus memiliki kemampuan untuk mengambil sudut pandang orang lain, atau melihat situasi dari sudut pandang orang lain (Lickona, 2012). Membayangkan dalam konteks Lickona bukan hanya dengan memahami sudut pandang orang lain yang bersifat imaginer, akan tetapi dengan membayangkan bagaimana mereka akan berpikir, berkreasi, dan merasa. Aspek inilah yang dianggap Lickona sebagai pra-syarat untuk mempertimbangkan moral (Lickona, 2004). 
Tahap keempat adalah penalaran moral, aspek ini berfungsi untuk memahami makna sebagai orang yang bermoral dan mengapa individu harus bermoral (Setiawan, 2013). Individu akan mampu mempelajari mana yang termasuk sebagai nalar moral dan mana yang tidak termasuk sebagai nalar moral ketika mereka melakukan tindakan konkret (Lickona, 2004). Aspek ini sangat mengedepankan penanaman prinsip-prinsip moral dalam berbagai situasi, karena dengan penalaran moral seseorang akan dapat memperlakukan orang dengan baik dikarenakan memiliki construct untuk mengaktualisasikan penalaran moral tersebut. Tahap kelima adalah membuat keputusan dan memahami diri sendiri, aspek ini sangat berfokus pada mepertimbangkan permasalahn dan mengevaluasi dirinya secara kritis. Pengambilan keputusan merupakan kemampuan yang reflektif, yang dikategorikan oleh Lickona sebagai sebuah "keterampilan" (Lickona, 2004). Sedangkan konten memahami diri sendiri merupakan pemahaman diri terhadap kelebihan dan kekurangan yang berimplikasi pada memperbaiki kelemahan-kelemahan dalam diri individu tersebut (Lickona, 2004). Tentunya moral knowing membutuhkan komponen lainnya seperti moral feeling dan moral action yang berfungsi dalam menunjang seseorang untuk menjadi "karakter yang baik".

\section{Moral Feeling $\mathcal{E}$ Moral Action}

Tindakan moral (moral action) adalah sebuah produk dari pengetahuan moral dan perasaan moral (Lickona, 1983). Ada tiga aspek yang dianggap Lickona sangat berpengaruh pada komponen ini, pertama adalah kompetensi moral. Kompotensi moral adalah kemampuan untuk mengubah pertimbanganpertimbangan dan perasaan moral kedalam sebuah tindakan moral yang efektif (Lickona, 2004). Selain berperan dalam mengkontruksikan sebuah tindakan, komponen ini juga berperan dalam situasi moral lainnya, seperti menghadapi kesulitan dan berbagai problem yang membutuhkan tindakan konkret dalam bentuk pemecahan masalah. Kedua ialah kehendak moral, yaitu kemampuan untuk membuat pilihan moral. Misal; Menjadi baik seringkali menuntut orang untuk melakukan tindakan yang nyata, memobilisasi energi moral yang bertujuan untuk melakukan apa yang menururt kita harus dilakukan (Lickona, 1983). Kehendak disini dibutuhkan untuk menjaga emosi agar tetap terkendali oleh akal, yang tentunya juga berfungsi untuk melihat dan memikirkan suatu keadaan melalui seluruh dimensi moral. Ketiga adalah kebiasaan (habit), Lickona menyatakan bahwa salah satu ciri orang berkarakter adalah orang yang memiliki kebiasaan yang baik, bertindak sungguh-sungguh, berani, dan konsisten dalam tindakan baiknya (Lickona, 2004).

Perasaan moral (moral feeling) merupakan komponen yang berfokus pada sisi emosional individu. Setidaknya ada lima aspek yang dijabarkan oleh Lickona dalam membangun perasaan moral, yaitu: hati 
nurani, menurut Lickona hati nurani terbagi menjadi dua, yaitu sisi kognitif dan sisi emosional. Self esteem, adalah bagaimana seseorang memandang dirinya positif, jika individu tersebut memandang dirinya positif maka tindakannya secara tidak langsung akan positif. Empati, adalah kemampuan untuk mengenali dan merasakan keadaan yang dirasakan oleh orang lain, karena empati adalah salah satu cara mengambil sudut pandang lain yang dapat mempengaruhi pengambilan keputusan. Kontrol diri, aspek ini sangat didasari pada kontrol diri, alasan mengapa Lickona berpendapat seperti ini didasari pada-bahwa emosi dapat menghanyutkan akal. Kerendahan hati dan mencintai kebaikan, merupakan pekerti moral yang kerap diabaikan oleh seseorang, Lickona berpendapat bahwa kerendahan hati sangat berpengaruh dalam cara memperlakukan orang lain, sedangkan mencintai kebaikan adalah ciri karakter tertinggi dalam diri seseorang (Lickona, 2004).

Pemikiran Lickona terhadap apa saja komponen dalam membentuk karakter yang baik mengantarkan kita pada suatu kesimpulan, bahwa komponen moral (pengetahuan, perasaan, dan tindakan moral) bekerja secara sistematis dan ter-integrasi dalam meujudkan karakter yang baik, akan tetapi Lickona juga tak melewatkan aspek "proses", karena setiap individu memiliki perkembangan moral yang berbedabeda.

\section{PENDIDIKAN KARAKTER PERSPEKTIF PSIKOLOGI ISLAM}

Sebelum berbicara mengenai pendidikan karakter dalam perspektif psikologi Islam, ada baiknya jika kita meninjau kembali apa yang dimaksud dengan psikologi Islam terutama di era modern saat ini. Psikologi Islam secara harfiah merupakan ilmu yang membahas perilaku maupun jiwa manusia dalam bingkai agama Islam (Ancok, 2011). Adapun secara spesifik psikologi Islam merupakan ilmu yang mengkaji tentang manusia (kepribadian) yang bersifat filsafat, teori, metodologi, dan pendekatan problem yang didasari sumber-sumber formal Islam (Al-Qur'an dan Hadist), akal, indera, dan intuisi (Yudiani, 2004). Psikologi islam pada dasarnya harus bersifat empiris terutama dalam ruang lingkup perilaku maupun moral (Skinner, 2019). Akan tetapi tentunya psikologi Islam juga mengandung unsur ilahiyah yang bertujuan untuk mengarahkan kualitas hidup (perilaku, karakter, dll) menuju lebih baik (Faridah, 2016). Uraian diatas setidaknya menjadi pintu gerbang bagaimana karakter ideal atau baik menurut perspektif psikologi Islam.

Dalam wacana Psikologi Islam karakter sejatinya merupakan personifikasi dari akhlak. Berkaitan dengan akhlaq Al-Ghazali mengemukakan dua citra manusia, yaitu citra lahiriah (khalaq), dan citra psikis (khuluq) (Mujib, 2012). Kedua citra ini merupakan kondisi (hay'ah) dalam jiwa (nafs) yang suci (rasikhah), kondisi ini menimbulkan suatu aktivitas yang mudah tanpa 
memerlukan pemikiran maupun pertimbangan terlebih dahulu. Akan tetapi Al-Jurjawi berpendapat bahwa akhlak itu hanya mencakup kondisi batiniah (inner), dan bukan merupakan kondisi lahiriah seperti yang diungkapkan oleh Al-Ghazali (Jurjawi, 1988). Dari penjelasan diatas setidaknya bahwa karakter dalam Psikologi Islam sebenarnya merupakan apa yang kita sebut dengan pendidikan akhlak, karena pada hakikatnya istilah apapun yang berkaitan dengan Islam maka akan terikat dengan nilai-nilai yang terkandung di Al-Qur'an.

Psikologi Islam dilandasi dengan keyakinan bahwa kebenarankebenaran yang hakiki terungkap secara verbal dalam firman Allah SWT, dan tersirat dalam sunatullah (hukum alam) (Hafizallah, 2019). Salah satu surat Al-Qur'an yang membahas tentang pendidikan akhlak dari perspektif Psikoloogi Islam adalah surat an-Nur ayat 30-31. Ayat ini membahas secara konseptual tentang karakteristik pendidikan akhlak. Pendidikan akhlak yang dimaksud pada ayat ini adalah pendidikan akhlak rabbani, akhlak manusiawi, akhlak universal, akhlak keseimbangan, dan akhlak realistik (Wafi, 2009). Adapun dalam tinjauan Psikologi Islam itu sendiri surat an-Nur ayat 30-31 merupakan produk substansial manusia yang terdiri dari unsur jiwa, hati, dan akal (Wafi, 2009). Tentunya hal ini tergantung pada pemahaman individu tentang ajaran agamanya beserta aktualisasinya yang berdasarkan pada nilai-nilai moral yang terkandung dalam aspek sosial individu tersebut.

Jika produk substansial dari Psikologi Islam merupakan unsur jiwa, hati, dan akal, maka acuan dalam karakter perspektif Islam merupakan elemen-elemen kepribadian. Dalam terminologi Islam kata "karakter" merupakan konotasi positif, sedangkan moralitas (akhlaq) yang berarti moral yang baik (al-akhlaq al-mahmudah) atau karakter buruk (al-akhlaq almadzmumah) dianggap sebagai konsep yang dikembangkan dengan istilahistilah agama, adapun konsep rasionalitas dan karakter berasal dari pengalaman manusia (Alhamdani, 2016). Konsep karakter, moral, nilai, dan etika yang sebenarnya memiliki tujuan yang sama pada tataran konsep khususnya dalam perpsektif Psikologi Islam. Akan tetapi memang para ilmuwan memiliki tafsir yang berbeda, yang berimplikasi pada munculnya berbagai konsep karakter maupun pendidikan.

\section{PENDIDIKAN KARAKTER LICKONA DALAM PERSPEKTIF PSIKOLOGI ISLAM}

Dalam Islam, tidak ada disiplin ilmu yang terpisah dari etika-etika Islam. Hal ini disebabkan karena dasar dari keilmuan Islam adalah Al-Qur'an dan Hadist. Komparasi antara akal dan wahyu sangat menentukan nilai-nilai moral yang sangat menarik untuk dikaji. Bagi kaum Muslim segala yang dianggap halal ataupun haram, baik ataupun buruk, dipahami sebagai kuptusan Allah SWT (Madjid, 2012). Islam memiliki tiga nilai-nilai utama 
yaitu, akhlak, adab, dan keteladanan, di mana pada garis besarnya pemikiran pendidikan karakter Thomas Lickona yang sangat berfokus pada kajiankajian moral sangat relevan dari segi konseptual.

Implementasi dari pemikiran Lickona pada hakikatnya adalah sifatsifat operatif seorang individu, yang artinya semua bentuk perilaku harus didasari oleh perhitungan moral dan dampak-dampak moral yang kemungkinan memiliki ambiguitas dari berbagai perspektif. Psikologi Islam sejatinya adalah ilmu yang membahas masalah perilaku seserorang yang terdiri dari azas-azas islam itu sendiri. Islam memiliki figur ideal baik secara keimanan ataupun karakter yaitu, Nabi besar Muhammad SAW (Madjid, 2012). Psikologi Islam secara harfiah dapat didefinisikan sebagai ilmu yang membahas perilaku maupun jiwa manusia dalam perspektif Islam (Ancok, 2011). Secara definisial Psikologi Islam memiliki konsep berperilaku yang didasari pada tiga aspek yaitu aspek jismiah, nafsiyah, dan ruhaniah (Baharuddin, 2008). Lantas bagaimana "menyingkap" relevansi antara pendidikan karakter Lickona dengan Psikologi Islam dimana setidaknya aspek-aspek moral yang terimplementasi dalam bentuk perilaku dapat berjalan se-ide dengan pembahasan ini. Sebelum mengulik lebih jauh relevansi kedua variabel ini, ada baiknya jika persoalan-persoalan Psikologi Islam kita fokuskan pada bagaimana karakter yang ideal menurut perspektif Psikologi Islam.
Terminologi perilaku dalam psikologi Islam sebenarnya tak akan bisa lepas dari peran akhlak, karena pada dasarnya akhlak adalah sebuah cerminan dari identitas karakter seseorang. Terkait dengan akhlak, alGhazali mengutarakan dua citra akhlak yaitu, citra lahiriah manusia (khalq), dan citra batiniah (khuluq). Khalq merupakan citra fisik manusia, sedangkan khuluq merupakan citra psikis seseorang. Kedua citra ini sejatinya mampu berdiri dengan konsep-konsep jismiah, nafsiyah, dan ruhaniah yang termaktub dalam wacana besar Psikologi Islam. Dalam Psikologi Islam istilah akhlak sebenarnya sangat identik dengan syakhshiyyah Islamiyyah, yang samasama memiliki definsi "karakter", karena konsep seperti ini akan tetap terikat dengan hukum-hukum Islam terkait dengan baik dan buruk. Lantas bagaimana akhlak bisa menjadi faktor yang dominan dalam pembentukan karakter, setidaknya ada dua faktor yang sangat berperan yaitu (Mujib, 2001):

a. Faktor Eksternal

Faktor ini berupa kebudayaan dan nilai-nilai, karakter seseorang tidak hanya serta merta tumbuh dengan dengan baik begitu saja, akan ada proses yang sangat panjang sehingga membuat manusia memiliki karakter Islam yang sesungguhnya. Asupan kebudayaan dan nilai-nilai merupakan salah satu cara praktis dan efisien, yang secara turun temurun telah terbukti 
melalui

pengembangan

kehidupan bangsa Indonesia dalam menjaga karakter sebuah bangsa.

b. Faktor Internal

\section{Aktualisasi}

potensi merupakan faktor internal dalam pembentukan karakter seseorang. Adanya keunikan dari satu inividu dengan individu lainnya menyebabkan rentang batasan antara karakter yang baik menurut setiap individu sangatlah berbeda. Keunikan ini pada hakikatnya membuat seseorang dapat membedakan mana yang harus diaktualisasikan dan mana yang harus dikendalikan, peranan faktor ini sangat bertumupu pada peran psikologi maupun konselor muslim.

Secara garis besar dapat dipahami bagaimana benang merah antara pendidikan karakter Lickona dengan karakter perspektif Psikologi Islam. Desain berpikir Lickona sebenarnya sangat relevan dengan konsep-konsep Islam pada umumnya, dimana nilai-nilai moral harus mampu ditransformasikan menjadi sebuah pemikiran yang operatif. Pemikiran operatif inilah yang mampu membuat seseorang bertindak dengan hal-hal yang sesuai dengan ketentuan moral. Hal ini sangat senada dengan faktorfaktor pembentukan karakter Psikologi Islam, dimana budaya dan aktualisasi potensi sangat memiliki peran demi terbentuknya karakter yang ideal. Budaya dalam hal pengembangan karakter sangat dipengaruhi oleh beberapa aspek seperti, keluarga, lingkungan, dan pola berpikir seseorang. Hal ini jelas sangat relevan dengan apa yang dinyatakan oleh Lickona tentantg karakter, dimana keluarga dan lingkungan adalah guru karakter pertama bagi seorang individu (Lickona, 1983).

\section{PERAN PSIKOLOGI ISLAM DALAM PEMBENTUKAN KARAKTER}

Peran psikologi Islam dalam pembentukan karakter sejatinya bertumpu pada pendidikan pembentukan karakter itu sendiri (character building), yang dalam islam disebut dengan pendidikan akhlak. Konsep Al-Qur'an tentang pendidikan karakter pada dasarnya sangat mengedepankan akhlak (karakter). Hal ini senada dengan apa yang disampaikan oleh Yusuf Qaradwhi yang menyatakan bahwa "Islam sejatinya adalah pendidikan manusia yang seutuhnya baik, akal, hati, rohani, dan jasmani; akhlak dan keterampilan. Allah selalu menargetkan umatnya untuk terus berada dalam kondisi makarim al-akhlaq dalam setiap aspek kehidupannya. Secara garis besar dapat kita pahami bahwa dalam psikologi Islam itu sendiri pendidikan karakter itu adalah satu kesatuan dengan pendidikan akhlak. Sangat menarik untuk dikaji bahwa pada dasarnya aspek-aspek psikologi Islam tentang Jismiah, Nafsiyah, dan Ruhaniah memiliki kontribusi yang sangat besar dalam perkembangan karakter seseorang. Adapun peran 
psikologi Islam secara konsep adalah sebagai berikut:

a. Jismiah

Jismiah secara definisi dapat diartikan sebagai organ fisik dan biologi manusia dengan segala perangkat-perangkatnya. Organ fisik-biologis manusia adalah organ fisik yang sangat sempurna dan kompleks diantara ciptaan Allah SWT lainnya. Aspek ini memiliki dua sifat dasar; 1) Berupa bentuk kongkret, yang berarti tubuh kasar yang tampak, 2) Berbentuk abstrak, berupa nyawa halus yang menjadi sarana kehidupan tubuh. Aspek ini pada dasarnya sangat tunduk kepada sunatullah dan hukum-hukum alam, ini disebabkan keberadaan hakikat dari sebuah kehidupan menurut aspek ini bersifat deterministik dan mekanistik (Ancok, 2011).

Sebagaimana uraian

diatas pendidikan karakter perspektif psikologi Islam sangat relevan dengan apa yang disebut dengan aspek jismiah. Hal ini dinyatakan oleh Ibn Sina bahwa pada dasarnya aspek ini memeliki tiga daya yaitu daya nutrisi, daya pertumbuhan, dan daya generatif (Najati, 2009). Ketiga daya ini memiliki peran secara jasmani yang berkelanjutan, daya daya nutrisi berfungsi mengolah makanan menjadi bentuk tubuh, daya pertumbuhan berfungsiuntuk pengolahanmakanan yang telah diresap tubuh agar mencapai kesempurnaan petumbuhan, sedangkan daya generatif adalah daya pengolahan secara harmonis unsur-unsur makanan yang ada didalam tubuh. Relevansi karakter pada aspek ini memeng terlihat tak kasat mata, akan tetapi psikologi Islam menganggap kesehatan tubuh, adalah awal dari karakter yang kuat.

b. Nafsiyah

Aspek Nafsiyah adalah keseluruhan dari kualitas khas manusia yang berupa, pikiran, perasaan, kemauan, dan kebebasan. Aspek ini merupakan persentuhan antara aspek jismiah dan ruhaniah, aspek ini bersifat spiritual, transenden, suci, bebas, dan cenderung pada kebaikan (Baharuddin, 2008). Aspek ini sejatinya sangat berperan dalam pembentukan karakter perspektif psikologi Islam, sebagaimana pada hakikatnya aspek ini bertujuan untuk mengatasi apa yang Lickona sebut denga istilah "kebutaan moral" (Lickona, 2004). Aspek nafsiyah dianggap memiliki peran yang paling kontibutif dalam pengembangam karakter seseorang, karena pada aspek ini manusia dituntut untuk mengetahui apa saja nilai-nilai moral yang terkandung dalam setiap perbuatan yang dilakukannya, baik dari sudut pandang orang lain maupun 
dari sudut paandnag individu itu sendiri. Hal-hal yang berkaitan dengan aspek nafsiyah ini tentunya sangat dipengaruhi oleh penalaran moral masing-masing individu, goals dari aspek nafsiyah ini adalah manusia mampu memahami diri sendiri dan tuhannya, dalam hal ini Allah SWT.

Jika kita telaah konsep pemikiran Lickona tentang pengetahuan moral yang berimplikasi pada aksi-aksi moral, sejatinya aspek nafsiyah juga merangkul dengan apa yang disebut pengetahuan moral. Persoalan mulai timbul jika kita melihat pendidikan karakter Lickona dari perspektif nasfiyah, dikarenakan adanya tumpang-tindih epistimologi terkait masalah pengetahuan moral versi Lickona dan Pengetahuan moral versi psikologi Islam. Hal ini disebabkan adanya dimensi alAql, Qalb, an-Nafs yang dalam pendidikan karakter Lickona itu sendiri ternyata terjadi pemisahan antara agama dan moral. Berikut adalah jabaran tentang al-Aql, Qalb, an-Nafs yang tidak lain merupakan dimensi-dimensi psikis manusia dari aspek nafsiyah:

1. An-Nafs

Dimensi ini adalah dimensi yang memiliki sifatsifat kebinatangan dalam sistem psikis manusia.
Namun demikian dapat diarahkan kepada kemanusiaan setelah mendapat pengaruh besar dari dimensi lainnya. Dimensi nafsu memiliki dua daya utama, yaitu, pertama, al-ghadab yakni menghindarkan diri dari halhal yang mencelakakan diri. Kedua, syahwaniyah, yakni mengejar hal-hal yang menyenangkan. Jadi dimensi ini, jika tidak terkendali akan mengantarkan manusia pada hidup yang hedonistik, seks, material dan lain-lain, begitu juga sebaliknya.

2. Al-Aql

Dimensi akal adalah dimensi psikis manusia, dimensi ini memiliki peranan penting berupa fungsi pikiran yang berupa kualitas insaniyah pada psikis manusia. Akal mampu memperoleh bukti-bukti argumentasi logis dan mampu menghasilkan konsep-konsep dengan cara mengaktualisasikan hal yang abstrak. Kemampuan akal juga dapat dipahami sebagai lawan dari tabiat dan kalbu. Akal mampu memperoleh kemampuan melalui nalar, tabiat mampu memperoleh pengetahuan melalui daya naluriah dan alamiah.

3. Qalb

Qalb adalah dimensi ketiga dari aspek nafsiyah, 
dimensi ini memiliki peranan yang sangat penting dalam memberikan sifat insaniyah (kemanusiaan) bagi psikis manusia. Dari sudut fungsi al-Qalb memiliki tiga fungsi yaitu, pertama, fungsi kognisi yang menimbulkan daya cipya; seperti berfikir, memahami, mengetahui,

memperhatikan, mengingat, dan melupakan. Kedua, fungsi emosi, yang menimbulkan daya rasa; seperti tenang, jinak atau sayang, santun dan penuh kasih sayang, kasar, takut, dengki, dan lain-lain. Ketiga, fungsi konasi, yaitu qalb yang baik, qalb yang tidak baik, dan qalb antara baik dan buruk.

c. Ruhaniah

Aspek ini adalah aspek psikis manusia yang bersifat spiritual dan transendental. Bersifat transendental karena memiliki potensi luhur batin manusia. Potensi luhur batin merupakan sifat dasar dalam diri manusia yang berasal dari ruh ciptaan Allah. Aspek ini memiliki 2 dimensi yaitu ar-ruh dan al-fitrah, dimensi ini berasal dari Allah SWT, keduanya sebelum menjadi manusia, merupakan milik Allah. Aspek ini senantiasa menampilkan dua hal yaitu sisi asal, dan sisi keberadaannya. Sisi asalnya berazaskan pada wilayah spiritual-transendental, sedangkan sisi keberadaannya berazaskan pada wilayah historis-empiris (Ancok, 2011).

1. Dimensi ar-Ruh

Dimensi ar-ruh seperti jabaran diatas berasal dari Allah SWT, ketika ar-ruh ada bersama badan (al-jism) dan jiwa (an-nafs), maka ruh memiliki daya yang dibawa dari asalnya, yaitu daya yang bernama daya spiritual (Purwanto, 2007). Daya inilah yang menjadi penyebab manusia membutuhkan agama. Kekuatan daya spiritual ini sangat berpengaruh pada perkembangan nafs, aql, qlab, dan ruh. Jika semua daya ini tersinkronisasi maka seseorang akan mampu mencapai tahap kesempurnaan, maka kekuatan daya spiritual juga akan mencapai kesempurnaan,

2. Dimensi al-Fitrah

Dimensi al-fitrah sebagai fkator psikis manusia bukan hanya memiliki serangkaian daya-daya, melainkan memiliki identitas yang bersifat esensial yang memberikan frame kemanusaiaan bagi an-nafs (jiwa) agar tidak melenceng dari sisi kemanusiaannya (Purwanto, 2007). Sebaliknya jika manusia telah kehilangan daya-daya jiwa 
manusia yang melampuai frame, maka manusia akan keluar dari fitrah kemanusiaannya, baik itu positif maupun negatif. Berikut adalah analogi Baharuddi tentang struktur jiwa manusia, yang mana krakter ideal tidak boleh keluar dari frame yang bisa membuat hilangnya fitrah kemanusiaannya.

Aspek Jismiah, Nafsiyah, dan Ruhaniah seperti yang dijabarkan diatas adalah konsep dalam membangun karakter (character building) dalam perspektif psikologi islam, yang artinya akan ada strukturstruktur yang ter-integrasi dalam mewujudkan bentuk karakter ideal dalam bingkai keilmuan psikologi Islam. Karakter dalam perspektif psikologi Islam sejatinya adalah kesatuan gejala badan dan jiwa yang bersinergi dengan perilaku-perilaku yang teraktualisasi dan memiliki nilai (akhlaq). Jadi jika ditelaah, gagasan pendidikan karakter Thomas Lickona sangat relevan dengan dunia Islam, dimana adanya pengetahuan moral, perasaan moral, dan tindakan moral. Akan tetapi perlu digaris bawahi bahwa pemisahan moralitas dan agama seperti yang ada dipemikiran Thomas Lickona, sangat tidak relevan dengan dunia Islam, dimana agama sudah menjadi pondasi dasar dari pemikiran Psikologi Islam.

\section{PENUTUP}

Pembahasan di atas menyimpulkan bahwa pendidikan karakter Thomas Lickona sangat relevan dalam segi gagasan kependidikan, akan tetapi tidak dalam lingkup kajian agama khusunya sains yang terintegrasi oleh nila-nilai Islam (Psikologi Islam), dimana Lickona sendiri memisahkan antara moral dan agama. Sedangkan di kehidupan bernegara di Indonesia yang menjunjung tinggi nilai-nilai pancasila, dan keagamaan, pemikiran Lickona akan tidak sangat relevan karena pemisahan moral dan agama. Dari segi gagasan pemikiran Lickona, yaitu, pengetahuan moral, perasaan moral, dan tindakan moral sangat relevan dengan kajian Psikologi Islam, dimana dikajian psikologi Islam sangat menekankan implementasi dari nilainilai akhlak, adab, dan keteladanan, yang ketiganya ini menuntut untuk diaplikasikan di dalam kehidupan bermasyarakat, dan sangat jelas pemikiran Lickona tentang pengetahuan moral, perasaan moral, dan tindakan moral, sangatlah relevan dengan kajian Psikologi Islam modern, akan tetapi perlu digaris bawahi bahwa Islam tidak memisahkan agama dan moralitas. 


\section{DAFTAR PUSTAKA}

Albertus. K. D. (2011). Pendidikan Karakter; Strategi mendidik anak di Zaman Global. Jakarta: Kompas Gramedia.

Al Hamdani, D. (2016). The character education in islamic education viewpoint. Jurnal Pendidikan Islam UIN Sunan Gunung Djati, 1(1), 98-109.

Baharuddin, 2008. Psikologi Agama dalam Perspektif Islam, Malang: UIN Malang Press.

Beachum, F. D., \& McCray, C. R. (2005). Changes and transformations in the philosophy of character education in the 20th century. Essays in Education, 14(1), 12.

Berkowitz, M. W., \& Bier, M. C. (2004). based character education. The Annals of the American Academy of Political and Social Science, 591(1), 72-85.

Donny, Setiawan (2013). Peran pendidikan karakter dalam mengembangkan kecerdasan moral. Jurnal Pendidikan Karakter, (1).

Ancok, D. (2011). Psikologi Islami: Solusi Islam Atas Problemproblem Psikologi, Yogyakarta: Pustaka Pelajar.

Faridah, Siti. "Metodologi Dalam Kajian Psikologi Islam." Jurnal Studia Insania 4.1 (2016): 69-78.

Hafizallah, Y. (2019). PSIKOLOGI ISLAM. Psychosophia: Journal of Psychology, Religion, and Humanity, 1(1), 1-19. Retrieved from https://jurnal.lp2msasbabel.a c.id/index.php/psc/article/vie $\mathrm{w} / 860$

Izfanna, D., \& Hisyam, N. A. (2012). A comprehensive approach in developing akhlaq: A case study on the implementation of character education at Pondok Pesantren Darunnajah. Multicultural Education \& Technology Journal, 6(2), 77-86.

Lubis, Masruroh. Konsep Pendidikan Karakter Dalam Perspektif Islam dan Barat: Studi Komparatif Pemikiran Nashih Ulwan dan Thomas Lickona. Al-Fikru, vol. 12, no. 2 (2018), hlm. 55.

Lickona, Thomas. 1991. Educating for Character: How Our Schools can Teach Respect and Responsibility. New York: Bantan Books.

Lickona, Thomas. (2004) Characters Matters: How to Help Our Children Develop Good Judgement, Integrity, and Other Essential Virtues. New York: Touchstone Rockfeller Center.

Lickona, Thomas. (1983). Raising Good Children: How to Help Your ChildrenFrom Birth Through The Teenage Years, New York: Bantam Hard Cover Edition

Lickona, T. (2009). Educating for character: How our Schools Can Teach Respect and Responsibility. Bantam.

Lickona, Thomas. Pendidikan Karakter ; Panduan Lengkap Mendidik 
siswa Menjadi Pintar dan baik, (2013), Bandung Nusa Media.

Lickona, Thomas. Pendidikan Karakter. Yogyakarta: Kreasi Wacana, 2012.

Maragustam, Filsafat Pendidikan Islam; Menuju Pembentukan Karakter Menghadapi Arus Global, Yogyakarta: Kurnia Kalam Semesta, 2016

Madjid, Abdul. Pendidikan Karakter Perspektif Islam. Bandung. PT Remaja Rosda Karya (2012)

Mujib, Abdul. Konsep Pendidikan Karakter Berbasis Psikologi Islam. Prosiding Seminar Nasional Psikologi Islami, (2012), hlm. 1-9.

Reilly, T. S., \& Narvaez, D. (2018). Character, Virtue, and Science: Linking Psychological and Philosophical Views. Philosophy, Theology and the Sciences, 5(1), hlm. 51-79.

Sanderse, Wouters. Does NeoAristotelian Character Education Maintain the Educational Status Quo? Lesson From the 19th Century Bildung Tradition, Journal Ethicts and Education (2019), hlm. 1-17. [https://doi.org/10.1080/17449 642.2019.1660456]

Setiawan, Deny. "Peran pendidikan karakter dalam mengembangkan kecerdasan moral." Jurnal Pendidikan Karakter 1 (2013).

Sihotang, Kasdin. (2018) Filsafat Manusia; Jendela
Menyingkap Humanisme. Yogyakarta: PT Kanisius.

Skinner, Rasjid. "Traditions, paradigms and basic concepts in Islamic psychology." Journal of religion and health 58.4 (2019): 1087-1094.

Watson, Lani. Educating for Inquisitiviness: A Case Against Exemplarism for Intellectual Character Eduacation. Journal of Moral Education, vol. 48, no. 3, hlm. 303-315.

[https://doi.org/10.1080/03057 240.2019.1589436]

Wibowo, Agus. (2014) Pendidikan Karakter di Perguruan Tinggi; Membangun Karakter Ideal Mahasiswa di Perguruan Tinggi. Yogyakarta: Pustaka Pelajar.

Wibowo, Agus. (2012) Pendidikan Karakter: Strategi Membangun Karakter Bangsa Berperadaban, Yogyakarta: Pustaka Pelajar.

In'amul Wafi. (1429) Prinsip Pendidikan Moral pada Surat an-Nur Ayat 30-31 dalam Perspektif Psikologi Islam, At-Ta'dib Vol. 4, No. 1.

Yudiani, Ema. (2004) "Pengantar Psikologi Islam." Jurnal Ilmu Agama UIN Raden Fatah 14.2: 175-186. 